\title{
COMPARISON OF EPIDURAL DEXMEDETOMIDINE AND NEOSTIGMINE USED AS ADJUVANT TO ROPIVACAINE IN LOWER LIMB SURGERIES
}

\author{
Major Vishal Arora', Mohammad Zafeer Khan², Akritie Bhadwal', Major Sanjay Choubey, Mohammad Asim Rasheed ${ }^{5}$, \\ Arindam Sarkar6, Vivek Singh ${ }^{7}$
}

\author{
${ }^{1}$ Associate Professor, Department of Anaesthesiology, ELMC \& H. \\ ${ }^{2}$ Assistant Professor, Department of Anaesthesiology, ELMC \& H. \\ 33 rd Year Junior Resident, Department of Anaesthesiology, ELMC \& H\& $H$. \\ 4 Professor, Department of Anaesthesiology, ELMC \& H. \\ ${ }^{5}$ Associate Professor, Department of Anaesthesiology, ELMC \& $H$. \\ ${ }^{6}$ Assistant Professor, Department of Anaesthesiology, ELMC \& H. \\ ${ }^{7}$ Assistant Professor, Department of Anaesthesiology, Rama Medical College, Kanpur.
}

\section{ABSTRACT}

\section{BACKGROUND}

Spinal anaesthesia was introduced in clinical practice by Karl August Bier in 1898. More than a century has passed and even today, it is one of the most popular techniques for both elective and emergency surgical procedures, particularly caesarean section, lower abdominal surgeries, orthopaedic and urological surgeries.

The aim of this study was to compare the onset and height of sensory and motor block, haemodynamics, duration of analgesia in post-operative period, number of rescue analgesic epidural doses administered in 24 hours and record complications.

Settings and Design - This was a prospective, randomised and single blind study conducted on 60 patients divided in 2 groups viz. Group RD and RN.

\section{MATERIALS AND METHODS}

Group RN received $15 \mathrm{~mL}$ of $0.75 \%$ ropivacaine with 5 microgram/kg Inj. Neostigmine while Group RD received $15 \mathrm{~mL}$ of $0.75 \%$ ropivacaine with 1 microgram $/ \mathrm{kg}$ of Inj. Dexmedetomidine.

Statistical Analysis Used- Unpaired Student's t test and Z test.

\section{RESULTS}

Dexmedetomidine emerged as superior drug when compared to neostigmine as an adjunct with epidural ropivacaine $0.75 \%$ for patients undergoing lower limb surgery because it provides faster onset of anaesthesia, better intraoperative and postoperative analgesia and prolonged duration of motor and sensory blockade without significant increase in adverse effects.

\section{CONCLUSION}

- Onset of sensory anaesthesia was faster with RD group (Ropivacaine and dexmedetomidine) in comparison with RN group (Ropivacaine and neostigmine).

- $\quad$ Maximum level of blockade achieved remains same. Time to attain maximum sensory level of T6-T7 and maximum motor blockade was faster when dexmedetomidine was used as additive when compared with neostigmine.

- Haemodynamic parameters remain unchanged during the surgery in both groups.

- Sedation was associated with epidural administration of both neostigmine and dexmedetomidine but more with dexmedetomidine.

- Dexmedetomidine emerged as superior drug when compared to neostigmine as an adjunct with epidural ropivacaine $0.75 \%$ for patients undergoing lower limb surgery and lower limb orthopaedic surgery because it provides faster onset of anaesthesia, better intraoperative and postoperative analgesia and prolonged duration of motor and sensory blockade without significant increase in adverse effects.

\section{KEYWORDS}

Dexmedetomidine, Ropivacaine, Neostigmine, Epidural.

HOW TO CITE THIS ARTICLE: Arora MV, Khan MZ, Bhadwal A, et al. Comparison of epidural dexmedetomidine and neostigmine used as adjuvant to ropivacaine in lower limb surgeries. J. Evolution Med. Dent. Sci. 2016;5(84):6264-6269, D0I $10.14260 /$ jemds/2016/1416

Financial or Other, Competing Interest: None.

Submission 15-09-2016, Peer Review 09-10-2016,

Acceptance 14-10-2016, Published 19-10-2016.

Corresponding Author:

Dr. Major Vishal Arora,

Wisdom Academy, Urmilapuri,

Kamta, Faizabad Road,

Lucknow-226028.

E-mail: arovish1974@gmail.com

DOI: $10.14260 /$ jemds/2016/1416

\section{BACKGROUND}

The introduction of neuraxial analgesia took place at the end of the 19th century. August Bier, a German surgeon, described six lower extremity operations rendered painless by means of "cocainisation of the spinal cord". Prior to 1904, the only drug available for neuraxial use was cocaine, and development of epidural technology was still a way off. Epidural local anaesthetics (LA) results in effective pain relief and improved GI motility compared with opioid based analgesia with minimal central nervous system and cardiovascular toxicities. 
The advantage of this technique is that graded epidural anaesthesia or supplementation of the drug is possible even during the surgery. Fewer narcotics are needed and other benefits are less hypertension, lesser amount of blood loss, short operation time, short post-operative recovery time, verbal communication with the patient, fewer side effects like pain, nausea, vomiting, urinary retention, headache, stress responses, thromboembolic events. ${ }^{1-3}$

Longer-acting local anaesthetics used for epidural blockade typically consist of either bupivacaine or ropivacaine in varying concentrations. Greater concentrations of either will produce a greater motor block in addition to the sensory block that is typically desired. Ropivacaine, the S-enantiomer is an amino amide, long acting local anaesthetic agent with a chemical structure similar to Bupivacaine, has a lesser intense and shorter duration of motor block in addition to a lower toxicity profile than an equipotent dose of bupivacaine. Hence, it appears that ropivacaine may be an ideal local anaesthetic agent for epidural anaesthesia with few side effects like less intense motor blockade. ${ }^{4}$ Ropivacaine is less lipophilic than bupivacaine and that together with its stereoselective properties, contributes to ropivacaine having a significantly higher threshold for cardiotoxicity and CNS toxicity than bupivacaine in animals, 5 and healthy volunteers. When ropivacaine was administered intravenously in subjects, its pharmacokinetics were linear and dose proportional up to 80 mg. ${ }^{6}$ The absorption of ropivacaine $150 \mathrm{mg}$ from the epidural space is complete and biphasic. The mean half-life of the initial phase is approximately 14 minutes, followed by a slower phase with a mean absorption $\mathrm{t}_{1 / 2}$ of approximately 4.2 hours. Ropivacaine has been a well-tolerated regional anaesthetic effective for surgical anaesthesia as well as the relief of postoperative and labour pain in a study by Gaurav Kuthiala and Geeta Chaudhary. 4 Different drugs have been used as adjuvants with ropivacaine to prolong the duration of intraoperative and postoperative analgesia. None of these adjuncts is an ideal agent. The use of opioids as adjuvant is associated with side effects such as nausea, vomiting, pruritis, urinary retention and respiratory depression. ${ }^{7}$

Dexmedetomidine, is currently considered a super selective alpha-2 adrenergic agonists prototype, with selectivity ratio between $\alpha_{2}$ : $\alpha_{1}$ receptors of 1600:1, thus reduce the unwanted side effects involving $\alpha_{1}$ receptors.

It was introduced in clinical practice in the United States in 1999 and approved by the FDA only as a short-term $(<24$ hours) sedative for mechanically ventilated adult ICU patients. Dexmedetomidine follows linear or zero-order kinetics, meaning that a constant amount of the drug is eliminated per hour. Dexmedetomidine is now being used off-label outside of the ICU in various settings, including sedation and adjunct analgesia in the operating room, sedation in diagnostic and procedure units, and for other applications such as withdrawal/detoxification. It is the most recent and advanced agent, used in clinical anaesthesia, having sedative, analgesic, haemodynamic stabilising effects in addition to reduction of anaesthetic drug requirement. Dexmedetomidine is reported to have synergistic effect with ropivacaine for epidural anaesthesia. The drug increases the duration of analgesia, intensify the motor block and prolongs the duration of postoperative analgesia. Dexmedetomidine produces sedation without significant respiratory depression.
Epidural neostigmine analgesia seems to be a result of central rather than peripheral action. In patients undergoing surgery, epidural neostigmine resulted in analgesia after the administration of a ten-fold lower dose $(1 \mu \mathrm{g} / \mathrm{kg})$, when compared to knee intraarticular administration, suggesting a central effect.8 Epidural neostigmine acts on the enzymes acetylcholinesterase and butyrylcholinesterase expressed in the meninges that cover the spinal cord.9,10 Another aspect to be considered is the possible direct action of neostigmine as a muscarinic agonist, ${ }^{11}$ in addition to the indirect stimulation of the release of the second intracellular messenger, nitric oxide. The neuraxial administration of neostigmine, one of a new class of analgesics, has been reported to be antinociceptive in humans and animals. Previous demonstration suggests that preincisional epidural administration of neostigmine reduces plasma cortisol levels and decreases postoperative pain.

The aim of this study is to compare the onset and height of sensory and motor block, the haemodynamics, the duration of analgesia of study drugs in post-operative period, the number of rescue analgesic epidural doses administered in 24 hours immediate post-operative period and record complications, if any.

\section{MATERIALS AND METHODS}

This was a prospective, randomized and single blinded study conducted on 60 patients divided in 2 groups viz. Group RD and RN.

\section{Inclusion Criteria}

Patients of grade ASA I and II, scheduled for elective lower abdominal and lower limb surgery and age between 20 to 50 years.

\section{Exclusion Criteria}

Patient refusal, patients with significant cardiovascular disease, renal failure, hepatic dysfunction and chronic pulmonary disease, obesity (BMI $>30 \mathrm{Kg} / \mathrm{m}^{2}$ ), patients with known contraindications to epidural anaesthesia drug, history of allergy or sensitivity to any of the study drugs.

The enrolled patients were randomized in two groups of 30 each $(n=30)$ using random number table. Medications were prepared in a 15-ml syringe labelled as "study drug" to maintain blinding. All physicians, patients, nursing staff, and data collector were blinded to the patient group assignment.

Group-RN (n=30)- Received $15 \mathrm{~mL}$ of $0.75 \%$ ropivacaine with 5 microgram/kg inj. Neostigmine.

Group-RD (n=30)- Received $15 \mathrm{~mL}$ of $0.75 \%$ ropivacaine with 1 microgram/kg of injection Dexmedetomidine.

The patients were visited a day before surgery for preanaesthetic check-up and standard pre-operative advice was given. On the day of surgery, patients were wheeled in operation theatre and non-invasive monitors like pulse oximeter, non-invasive blood pressure (NIBP) and ECG were attached. The baseline parameters were recorded. Inside the Operation Theatre, 18 G IV access was secured and Ringer's lactate was commenced @ 5-8 mL/minute. Patients were made to sit and under strict aseptic precautions, 18G Tuohy needle was inserted into L2-L3 interspinal epidural space. Epidural space was confirmed by loss of resistance method and catheter was inserted and fixed between 9 and $10 \mathrm{~cm}$ mark. After institution of test dose $(3 \mathrm{~mL}$ inj. Xylocaine $0.5 \%$ with adrenaline, haemodynamic parameters were be recorded 
at baseline (T0), immediately after study drug is given (T1), every 5 minutes there after till 15 minutes and then every 15 minutes thereafter till end of surgery. Other parameters such as onset and height of sensory block and onset of motor block were also recorded.

Sensory blockade was assessed using pinprick sensation in mid-axillary line bilaterally. The onset of sensory block was considered at T10 and surgical procedure was initiated after establishment of adequate surgical analgesic effect with level of up to T7-T8 dermatome

Patients who experienced pain in the intra op period were excluded from the study, while the Modified Bromage scale was used to measure motor blockade. Onset of motor blockade was considered when Bromage scale changed from 0 to 1 and complete motor block was said at Bromage scale 3.12

\begin{tabular}{|c|c|c|}
\hline Grade & Criteria & Degree of block \\
\hline 0 & Full flexion of knees and feet & Nil (0\%) \\
\hline I & $\begin{array}{c}\text { Just able to flex knees, } \\
\text { full flexion of feet }\end{array}$ & Partial (33\%) \\
\hline II & $\begin{array}{c}\text { Unable to flex knees, but some } \\
\text { flexion of feet possible }\end{array}$ & $\begin{array}{c}\text { Almost } \\
\text { Complete }(66 \%)\end{array}$ \\
\hline III & Unable to move legs or feet & Complete (100\%) \\
\hline
\end{tabular}

After completion of surgery, the patient was shifted to post-operative ward and haemodynamic parameters were recorded in Post-operative period at every 30 minute interval. Sensory blockade were assessed using pinprick sensation in mid-axillary line bilaterally. Motor block was assessed immediately after sensory block assessment using Bromage Score. The time to first incidence of pain (VAS > 4), total duration of analgesia and the number of rescue analgesic $(10$ $\mathrm{mL}$ of $0.2 \%$ of inj. Ropivacaine) epidural doses were recorded during the first 24 hours. Pain was assessed by using 10 point Visual Analogue Scale (VAS) in which a score of " 0 " was indicate "no pain" and a score of " 10 " "worst pain imaginable".

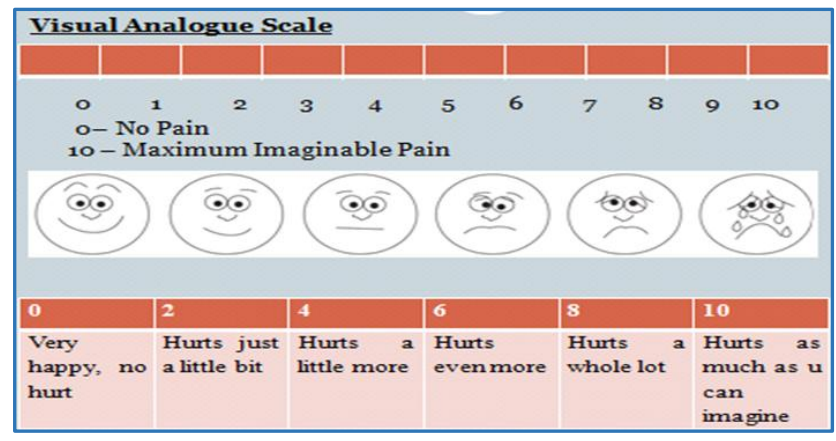

Sedation assessed by four point score described by Thimmappa et al.

Grade 0-Patient wide awake.

Grade 1-Patient is sleeping comfortably, but responding to verbal commands,

Grade 2-Deep sleep but arousable,

Grade 3-Deep sleep, unarousable.

\section{Following Parameters Were Recorded}

\section{- Haemodynamic Parameters}

Haemodynamic data, including systolic pressure, diastolic pressure, mean arterial pressure, and heart rate were recorded every two min.in the first $10 \mathrm{~min}$. after epidural anaesthesia, then every 5 minutes till 30 minutes until motor and sensory recovery.

\section{- $\quad$ Adverse Events}

(Hypotension, bradycardia, sedation, nausea and vomiting, shivering, pruritus etc) were recorded during operation and recovery.

Hypotension (Defined by decrease in MAP below $20 \%$ of baseline or SBP $<90 \mathrm{mmHg}$ ) was treated by Inj. Mephentermine $6 \mathrm{mg} / \mathrm{ml}$. Bradycardia (HR $<50 \mathrm{bpm}$ ) was treated by atropine $0.6 \mathrm{mg}$. Respiratory depression (RR $<8$ breaths per min. or $\mathrm{SpO}_{2}<95 \%$ ) was treated by oxygen supplementation and respiratory support. (If required).

\section{STATISTICAL ANALYSIS}

The results obtained in the study were presented in a tabulated manner as Mean \pm SD and were analysed using with Statistical Package for Social Sciences (SPSS 20.0). The demographic data for categorical variables were compared using Chi Square Test and statistical significance in mean difference was done by using analysis of variance (Unpaired sample T-test). ' $p$ ' value of $<0.05$ was considered as statistically significant.

\section{RESULTS}

As shown in Table 1, mean age in group RD was 32.77 \pm 9.1 years while in group $\mathrm{RN}$ mean age was $36.10 \pm 9.7$ years. The difference in mean age in both the groups was statistically not significant $(\mathrm{p}=0.176)$. Height was $165.70 \pm 5.9 \mathrm{~cm}$ in RD group whereas in RN group was $167.17 \pm 6.0 \mathrm{~cm}$. The difference in the height in both the groups was statistically insignificant. ( $p=$ $0.344)$. Although, in RD group weight was comparatively more $(65.53 \pm 9.5 \mathrm{~kg})$ as compared to group RN $(62.67 \pm 7.9 \mathrm{~kg})$ but it was statistically insignificant. $(\mathrm{p}=0.208)$ Sex ratio (Male:Female) was 24:6 and 23:7 for both the group respectively. In both the groups number of male patients were more as compared to females but the difference between both the groups was statistically insignificant. $(p=1.000)$. ASA grade (I/II) was (10/20) and (16/14) for the group RD and RN respectively, however the difference between both the groups was statistically insignificant. ( $\mathrm{p}=0.192)$. Duration of surgery was $162.90 \pm 14.1$ minutes in group RD and RN was $170.70 \pm 8.6$ minutes. The difference in both the group was statistically insignificant. $(\mathrm{p}=0.012)$.

As shown in Table 2, Figure 1, Base heart rate (Per minute) was statistically significant between the two groups $(\mathrm{p}<0.05)$ Baseline heart rate of patients in group RD was 88.40 \pm 15.9 minute and in group $\mathrm{RN}$ was $101.07 \pm 13.19$ (per minute) respectively. In group RD systolic blood pressure (mm $\mathrm{Hg}$ ) of patients was $133.30 \pm 11.2$ similarly in group $\mathrm{RN}$ was $134.43 \pm 13.0$ (mm Hg) respectively, which was not significant statistically. ( $p=0.742)$. Baseline diastolic blood pressure ( $\mathrm{mm}$ $\mathrm{Hg}$ ) of patients in group RD was $85.20 \pm 9.0$ whereas the same in group $\mathrm{RN}$ was $84.47 \pm 9.4$ respectively and was statistically insignificant $(\mathrm{p}=0.759)$. Mean arterial pressure was statistically insignificant in group RD was $81.60 \pm 9.1 \mathrm{~mm} \mathrm{Hg}$ and for group RN, was $85.27 \pm 7.6 \mathrm{~mm} \mathrm{Hg}$. (>0.05).

As shown in Table 3 and Figure 2 while mean time required to achieve T10 sensory block was $8.10 \pm 1.0$ minutes for group RD, the corresponding figure was $15.03 \pm 1.7$ minutes for patients of group RN. Onset was comparatively earlier in group RD than in Group RN. $(\mathrm{p}<0.001)$. The mean time period 
required for attainment of maximum sensory level (T7-T8) was also higher $(13.23 \pm 1.4$ minutes $)$ for group $\mathrm{RD}$ as compared group RN patients $(20.80 \pm 1.9$ minutes). The difference in time period requirement for achieving T10 sensory block and time to attain maximum sensory level between the patients of two groups was highly significant $(\mathrm{p}<0.001)$.

Mean time required for onset of motor block was earlier in group RD which was $15.10 \pm 1.5$ minutes in comparison to group $\mathrm{RN}$ patients which was $22.77 \pm 1.4$ minutes. The mean time requirement for complete motor block for group RD which was earlier was $17.60 \pm 1.7$ minutes, as against time requirement by group $\mathrm{RN}$ was $26.20 \pm 1.4$ minutes. The difference in time requirement for onset of motor block and complete motor block between the two groups was highly significant $(\mathrm{p}<0.001)$.

Although mean of pulse rate (Per minute) in group RD was $82.30 \pm 9.9$ and in group RN was $83.58 \pm 10$; however, it was insignificant statistically $(\mathrm{p}=0.638)$ and no statistical significant difference was found in SBP and DBP in both groups. ( $p>0.05)$ as depicted in Table 4 and Figure 3.

Sedation score was comparatively higher in group RD (2.16) than in group RN (1.77). However, it was statistically insignificant. $(\mathrm{p}=0.059)$.

(Table 5) First analgesia was necessitated after a mean time period of $329.90 \pm 16.1$ minutes in patients of group RD, likewise after a mean of $210.77 \pm 11.3$ minutes to the patients in group $\mathrm{RN}$ and this difference of time period in analgesic requirement between the two groups was highly significant $(p<0.001)$. Total dose of ropivacaine for rescue analgesia in post-operative period was lesser in group RD $(58.00 \pm 9.6 \mathrm{mg})$ as compared to group RN which was $76.67 \pm 9.2 \mathrm{mg}$ and this difference was highly significant $(\mathrm{p}<0.001)$.

Total number of rescue analgesia doses required in 24 hours in group RD $(2.90 \pm 0.5)$ were lesser as compared to group $R N(3.83 \pm 0.5)$ which was highly significant ( $\mathrm{p}<0.001)$.

The statistical difference in respect of adverse effects (Figure 4 ) in both the groups were not significant $(p>0.05)$. The effects were taken care of by suitable medication. In group RD, 9 out of 30 patients were found to have hypotension as compared to group RN with 4 patients out of 30 (Table 6).

\begin{tabular}{|c|c|c|c|c|}
\hline \multirow{3}{*}{\multicolumn{2}{|c|}{ Demographic Data }} & \multicolumn{2}{|c|}{ Groups } & \multirow{3}{*}{$\begin{array}{c}P \\
\text { value }\end{array}$} \\
\hline & & \multirow{2}{*}{$\begin{array}{c}\text { Group RD } \\
\text { Mean } \pm \text { SD }\end{array}$} & \multirow{2}{*}{$\begin{array}{l}\text { Group RN } \\
\text { Mean } \pm \text { SD }\end{array}$} & \\
\hline & & & & \\
\hline \multicolumn{2}{|c|}{ Age* (Year) } & $32.77 \pm 9.1$ & $36.10 \pm 9.7$ & 0.176 \\
\hline \multicolumn{2}{|c|}{ Height* $(\mathrm{cm})$} & $165.70 \pm 5.9$ & $167.17 \pm 6.0$ & 0.344 \\
\hline \multicolumn{2}{|c|}{ Weight* $(\mathrm{kg})$} & $65.53 \pm 9.5$ & $62.67 \pm 7.9$ & 0.208 \\
\hline \multirow{2}{*}{ Sex\# } & Male & $24(80.0 \%)$ & $23(76.7 \%)$ & \multirow{2}{*}{1.000} \\
\hline & Female & $6(20.0 \%)$ & $7(23.3 \%)$ & \\
\hline \multirow{2}{*}{$\begin{array}{c}\text { ASA } \\
\text { Grade\# }\end{array}$} & I & $10(33.3 \%)$ & $16(53.3 \%)$ & \multirow{2}{*}{0.192} \\
\hline & II & $20(66.7 \%)$ & $14(46.7 \%)$ & \\
\hline \multicolumn{5}{|c|}{$\begin{array}{l}\text { Table 1. Showing Demographic } \\
\text { Data between Both Groups }\end{array}$} \\
\hline
\end{tabular}

\begin{tabular}{|c|c|c|c|c|}
\hline \multicolumn{2}{|c|}{ Parameters } & $\begin{array}{l}\text { Group RD } \\
\text { Mean } \pm \text { SD }\end{array}$ & $\begin{array}{l}\text { Group RN } \\
\text { Mean } \pm \text { SD }\end{array}$ & P value \\
\hline \multicolumn{2}{|c|}{$\begin{array}{l}\text { Base Heart Rate* } \\
\text { (Per minute) }\end{array}$} & $88.40 \pm 15.9$ & $101.07 \pm 13.1$ & $<0.001$ \\
\hline \multirow{2}{*}{$\begin{array}{l}\text { Base Blood } \\
\text { Pressure }\end{array}$} & $\begin{array}{c}\text { SBP* } \\
\text { (mmHg) }\end{array}$ & $133.30 \pm 11.2$ & $134.43 \pm 13.0$ & 0.742 \\
\hline & $\begin{array}{c}\text { DBP* (mm } \\
\mathrm{Hg})\end{array}$ & $85.20 \pm 9.0$ & $84.47 \pm 9.4$ & 0.759 \\
\hline
\end{tabular}

\begin{tabular}{|c|c|c|c|}
\hline $\begin{array}{c}\text { Base MAP* } \\
\text { (mmHg) }\end{array}$ & $81.60 \pm 9.1$ & $85.27 \pm 7.6$ & 0.096 \\
\hline \multicolumn{2}{|c|}{ Table 2. Baseline Parameters in Both the Groups } \\
\hline
\end{tabular}

\begin{tabular}{|c|c|c|c|}
\hline & $\begin{array}{l}\text { Group } \\
\text { RD }\end{array}$ & Group RN & $\begin{array}{c}\mathbf{P} \\
\text { value }\end{array}$ \\
\hline $\begin{array}{l}\text { Time to Achieve T10 } \\
\text { Sensory Block*(min.) }\end{array}$ & $8.10 \pm 1.0$ & $15.03 \pm 1.7$ & $<0.001$ \\
\hline $\begin{array}{c}\text { Time to Attain } \\
\text { Maximum Sensory } \\
\text { Level*(min.) }^{*}\end{array}$ & $13.23 \pm 1.4$ & $20.80 \pm 1.9$ & $<0.001$ \\
\hline $\begin{array}{l}\text { Onset of Motor Block* } \\
\text { (min.) }\end{array}$ & $15.10 \pm 1.5$ & $22.77 \pm 1.4$ & $<0.001$ \\
\hline $\begin{array}{l}\text { Complete Motor Block* } \\
\text { (min.) }\end{array}$ & $17.60 \pm 1.7$ & $26.20 \pm 1.4$ & $<0.001$ \\
\hline \multicolumn{4}{|c|}{$\begin{array}{c}\text { Table 3. Onset of Sensory, Motor Block and } \\
\text { Complete Motor and Sensory Block in Both Groups }\end{array}$} \\
\hline
\end{tabular}

\begin{tabular}{|c|c|c|c|c|c|}
\hline \multirow{3}{*}{$\begin{array}{c}\text { Intra } \\
\text { Operative }\end{array}$} & \multicolumn{4}{|c|}{ Group } & \multirow{3}{*}{$\begin{array}{c}P \\
\text { value }\end{array}$} \\
\hline & \multicolumn{2}{|c|}{ Group RD } & \multicolumn{2}{|c|}{ Group RN } & \\
\hline & $\mathbf{N}$ & Mean \pm SD & $\mathbf{N}$ & Mean \pm SD & \\
\hline $\begin{array}{c}\text { Pulse } \\
\text { (Per Minute) }\end{array}$ & 30 & $\begin{array}{c}82.30 \pm \\
9.9\end{array}$ & 30 & $\begin{array}{c}83.58 \pm \\
10.9\end{array}$ & 0.638 \\
\hline $\begin{array}{c}\text { Mean } \\
\text { Arterial } \\
\text { Pressure } \\
\text { (Per Minute) }\end{array}$ & 30 & $\begin{array}{c}72.83 \pm \\
8.3\end{array}$ & 30 & $\begin{array}{c}75.95 \pm \\
7.4\end{array}$ & 0.349 \\
\hline $\begin{array}{l}\text { Systolic } \\
\text { Blood } \\
\text { Pressure } \\
\text { (mmHg) }\end{array}$ & 30 & $\begin{array}{c}117.42 \pm \\
9.4\end{array}$ & 30 & $\begin{array}{c}115.66 \pm \\
7.2\end{array}$ & 0.414 \\
\hline $\begin{array}{l}\text { Diastolic } \\
\text { Blood } \\
\text { Pressure } \\
\text { (mmHg) }\end{array}$ & 30 & $75.05 \pm 6.3$ & 30 & $\begin{array}{c}74.39 \pm \\
6.7\end{array}$ & 0.695 \\
\hline ( & & $\begin{array}{l}\text { Intraope } \\
\text { ic Param }\end{array}$ & t & $\begin{array}{l}\text { Iean of } \\
\text { Both Gro }\end{array}$ & \\
\hline
\end{tabular}

\begin{tabular}{|c|c|c|c|}
\hline & \multicolumn{2}{|c|}{ Groups } & \multirow{3}{*}{$\begin{array}{c}P \\
\text { value }\end{array}$} \\
\hline & \multirow{2}{*}{\begin{tabular}{|c|}
$\begin{array}{c}\text { Group } \\
\text { RD }\end{array}$ \\
Mean \pm SD \\
\end{tabular}} & \multirow{2}{*}{$\begin{array}{c}\text { Group } \\
\text { RN } \\
\text { Mean } \pm \text { SD }\end{array}$} & \\
\hline & & & \\
\hline $\begin{array}{l}\text { Time to 1st analgesic } \\
\text { requirement* (min.) }\end{array}$ & $\begin{array}{c}329.90 \pm \\
16.1\end{array}$ & $\begin{array}{c}212.77 \pm \\
11.3\end{array}$ & $<0.001$ \\
\hline $\begin{array}{c}\text { Total dose of } \\
\text { ropivacaine } \\
\text { for rescue analgesia } \\
\text { in } 24 \text { hours (mg) and } \\
\text { in mL }\end{array}$ & $\begin{array}{c}58.00 \pm 9.6 \\
20.90\end{array}$ & $\begin{array}{c}76.67 \pm 9.2 \\
30.83\end{array}$ & $<0.001$ \\
\hline $\begin{array}{l}\text { Total no. of rescue } \\
\text { analgesia }\end{array}$ & $2.90 \pm 0.5$ & $3.83 \pm 0.5$ & $<0.001$ \\
\hline
\end{tabular}

Table 5. $1^{\text {st }}$ Rescue Analgesic, Total Dose of Rescue Analgesia and No. of Rescue Analgesics in Both Groups

\begin{tabular}{|c|c|c|c|}
\hline Adverse Effects & $\begin{array}{c}\text { Group } \\
\text { RD }\end{array}$ & $\begin{array}{c}\text { Group } \\
\text { RN }\end{array}$ & $\begin{array}{c}\text { P } \\
\text { value }\end{array}$ \\
\hline Bradycardia\# & $1(3.3 \%)$ & $0(0.0 \%)$ & 1.000 \\
\hline Hypotension\# & $9(30.0 \%)$ & $4(13.3 \%)$ & 0.209 \\
\hline $\begin{array}{c}\text { Oxygen } \\
\text { Desaturation\# }\end{array}$ & $0(0.0 \%)$ & $0(0.0 \%)$ & - \\
\hline PDPH\# & $0(0.0 \%)$ & $0(0.0 \%)$ & - \\
\hline Shivering\# & $1(3.3 \%)$ & $0(0.0 \%)$ & 1.000 \\
\hline Nausea\# & $0(0.0 \%)$ & $(0.0 \%)$ & - \\
\hline Vomiting\# & $0(0.0 \%)$ & $0(0.0 \%)$ & - \\
\hline Itching\# & $0(0.0 \%)$ & $0(0.0 \%)$ & - \\
\hline Table 6. Showing Adverse Effects in Both Groups \\
\hline
\end{tabular}




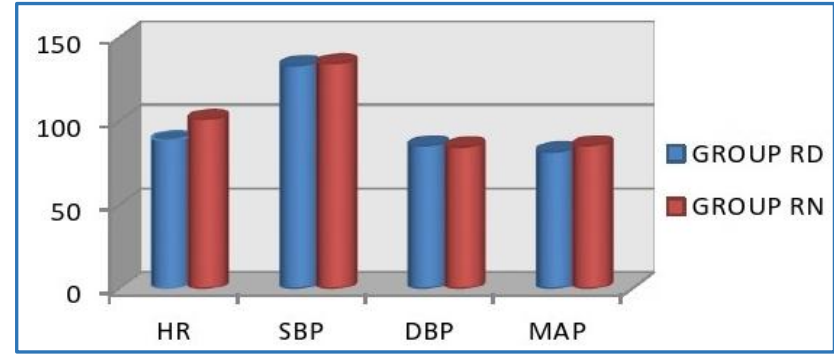

Figure 1. Baseline Parameters

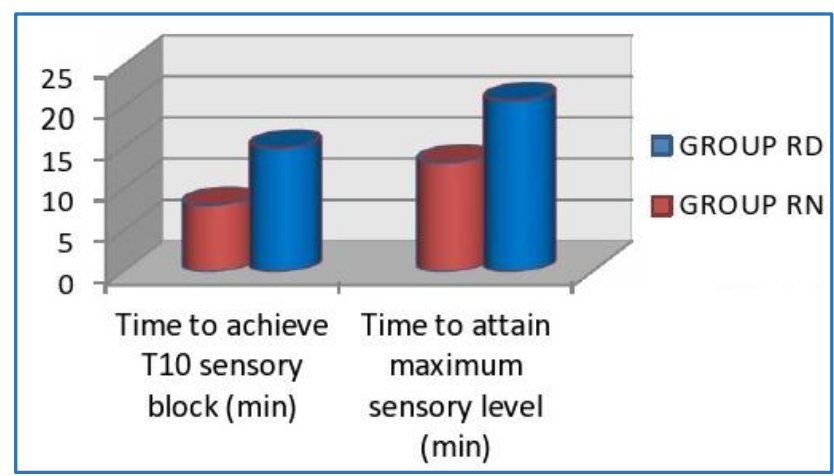

Figure 2. Time to Attain T10 and Max Sensory

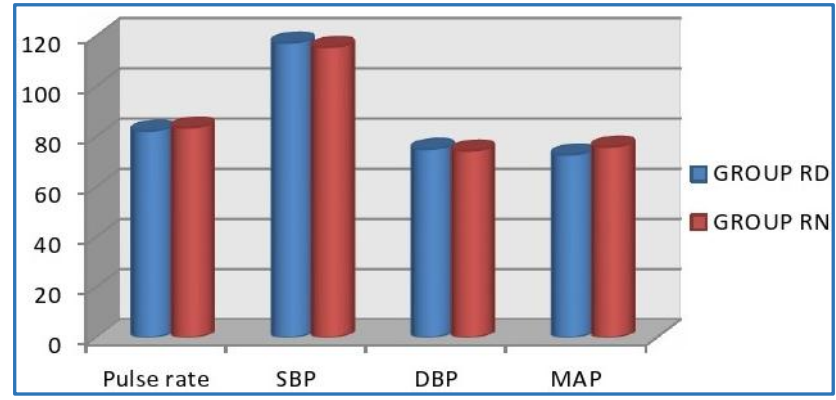

Figure 3. Intraop haemodynamics

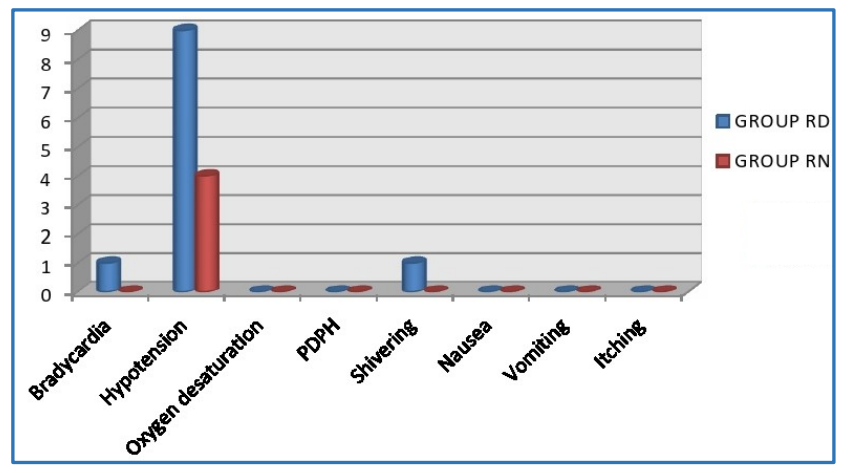

Figure 4. Adverse Effects

\section{DISCUSSION}

Central neuraxial blockade in the form of epidural is very popular for lower abdominal and lower limb surgeries as these techniques avoid the disadvantages associated with general anaesthesia like airway manipulation, poly pharmacy and other untoward effects like postoperative nausea, vomiting, need for supplemental intravenous analgesics. ${ }^{12}$ Epidural anaesthesia can be used as sole anaesthetic for procedures involving the lower limbs, pelvis, perineum and lower abdomen. It has the ability to maintain continuous anaesthesia after placement of an epidural catheter, thus making it suitable for procedures of long duration.
The basic characteristics of two groups (Group RD and Group RN) were compared and the statistical analysis revealed similar age $(p=0.176)$, proportion of genders $(p=1.00)$, height $(\mathrm{p}=0.344)$, weight $(\mathrm{p}=0.208)$, ASA grade $(\mathrm{p}=0.192)$ and duration of surgery $(p=0.062)$ between both groups, respectively i.e. did not differ significantly $(p>0.05)$ and the subjects of two groups were thus comparable. Vikas Singh et al13 and Manjunath Thimmappa et al ${ }^{12}$ also reported also a similar demographic profile among their studied groups.

Onset of sensory block was comparatively earlier in group RD than in Group RN. ( $\mathrm{p}<0.001)$ Vikas Singh et al ${ }^{13}$ in their study, they found that onset of analgesia was shorter in dexmedetomidine group $(8.10 \pm 1.0 \mathrm{~min}$. $)$ along with prolonged duration of analgesia when compared to Neostigmine group with mean onset of $15.03 \pm 1.7 \mathrm{~min}$. Bajwa SJ et al ${ }^{14}$ found that onset of analgesia was shorter in RD group along with prolonged duration of analgesia when compared to RC group. This study shows that time to attain maximum sensory level of T6-T7 was faster in Group RD when compared to Group RN $(p<0.001)$ which is statistically significant. Spinal neostigmine alone produces analgesia in humans and animals at doses greater than $100 \mu \mathrm{g} .{ }^{15}$ Taheri et al reported that duration of analgesia was not prolonged in patients who received bupivacaine plus neostigmine.

In our study, it was found that establishment of complete motor blockade was faster in Group RD when compared to Group RN ( $\mathrm{p}<0.001)$ which is statistically significant. Liu et al studied dose-response effects of spinal neostigmine added to bupivacaine spinal anaesthesia and found that the addition of 50 microgram neostigmine significantly increased the duration of motor block. Kanazi et $\mathrm{al}^{16}$ stated in their study that patients in groups D (12 mg of bupivacaine supplemented with $3 \mu \mathrm{g}$ of dexmedetomidine) and C (12 $\mathrm{mg}$ of bupivacaine supplemented with $30 \mu \mathrm{g}$ of clonidine) had a significantly shorter onset time of motor block. This shows that addition of dexmedetomidine hastens the maximum motor block compared to clonidine. ${ }^{14,17}$

In our study, the duration of analgesia was significantly longer in Group RD when compared to Group RN ( $\mathrm{p}<0.001)$. However, from this it is observed that addition of additives like neostigmine and dexmedetomidine intensifies the motor blockade.

Vikas Singh et al 13 in their study revealed significantly different time to 1 st analgesic requirement $(F=132.24$, $\mathrm{p}<0.001$ ) and the time to 1 st analgesia requirement was significantly delayed in both Group $\mathrm{R}+\mathrm{D}(\mathrm{p}<0.001)$ and Group $\mathrm{R}+\mathrm{N}(\mathrm{p}<0.001)$ as compared to Group R. Further, the time to 1 st analgesia requirement in Group $\mathrm{R}+\mathrm{D}(\mathrm{p}<0.05)$ although Kaya FN et al trial ${ }^{18}$ reported fewer patients requesting postoperative analgesic supplementation in the dexmedetomidine group which is comparable to our study.

Sabbe ${ }^{19}$ et al concluded that dexmedetomidine produces a powerful antinociceptive effect, mediated at the spinal level, while systemic redistribution of the drug leads to a hypnotic state. The maximum sedation was significantly higher in Group R+D as compared to both Group R $(\mathrm{p}<0.001)$ and Group $\mathrm{R}+\mathrm{N}(\mathrm{p}<0.001)$ as also reported by Vikas Singh et al. ${ }^{13}$

In this study, haemodynamic parameters remain unchanged during the surgery in both groups. Liu et $\mathrm{al}^{20}$ studied dose-response effects of spinal neostigmine added to bupivacaine spinal anaesthesia and found that neostigmine at $50 \mathrm{mcg}$ dose had no effect on haemodynamic parameters. 
Kanazi et al ${ }^{16}$ concluded in their study that addition of $3 \mu \mathrm{g}$ dexmedetomidine or $30 \mu \mathrm{g}$ clonidine to $12 \mathrm{mg}$ bupivacaine did not produce significant change in heart rate.

The statistical differences in respect of adverse effects in both the groups were not significant $(\mathrm{p}>0.05)$. Because of low dose of neostigmine, we did not find nausea and vomiting. Lauretti et al in a multicentre, placebo-controlled trial investigated the effects of $25-75 \mathrm{mcg}$ intrathecal neostigmine and found that only the $75 \mathrm{mcg}$ dose of neostigmine increased the nausea score in the recovery room. Vikas Singh et al ${ }^{13}$ compared the proportion (Y/N) of each observed adverse effect between the $\mathrm{R}+\mathrm{N}$ (Ropivacaine and neostigmine) and $\mathrm{R}+\mathrm{D}$ groups (Ropivacaine and dexmedetomidine), $\chi 2$ test revealed significantly higher Nausea $(\chi 2=35.11, p<0.001)$ and Vomiting $(\chi 2=26.85, \mathrm{p}<0.001)$ in Group $\mathrm{R}+\mathrm{N}$ as compared to Group R+D. However, rest of the adverse effects were similar $(p>0.05)$ between both the groups.

\section{CONCLUSION}

- $\quad$ Onset of sensory anaesthesia was faster with RD group (Ropivacaine and dexmedetomidine) in comparison with RN group (Ropivacaine and neostigmine).

- Maximum level of blockade achieved remains same. Time to attain maximum sensory level of T6-T7 and maximum motor blockade was faster when dexmedetomidine was used as additive when compared with neostigmine.

- Haemodynamic parameters remain unchanged during the surgery in both groups.

- Sedation was associated with epidural administration of both neostigmine and dexmedetomidine but more with dexmedetomidine.

- Dexmedetomidine emerged as superior drug when compared to neostigmine as an adjunct with epidural ropivacaine $0.75 \%$ for patients undergoing lower limb surgery and lower limb orthopaedic surgery because it provides faster onset of anaesthesia, better intraoperative and postoperative analgesia and prolonged duration of motor and sensory blockade without significant increase in adverse effects.

\section{REFERENCES}

1. Papadopoulos EC, Girardi FP, Sama A, et al. Lumbar microdiscectomy under epidural anesthesia: a comparison study. Spine J 2006;6(5):561-4.

2. Demirel CB, Kalayci M, Ozkocak I, et al. A prospective randomized study comparing perioperative outcome variables after epidural or general anesthesia for lumbar disc surgery. J Neurosurg Anesthesiol 2003;15(3):185-92.

3. Jellish WS, Thalji Z, Stevenson K, et al. A prospective randomized study comparing short and intermediateterm perioperative outcome variables after spinal or general anesthesia for lumbar disk and laminectomy surgery. Anesth Analg 1996;83(3):559-64.

4. Kuthiala G, Chaudhary G. Ropivacaine: a review of its pharmacology and clinical use. Indian J Anaesth 2011;55(2):104-10.

5. Graf BM, Abraham I, Eberbach N, et al. Differences in cardiotoxicity of bupivacaine and ropivacaine are the result of physicochemical and stereoselective properties. Anesthesiology 2002;96(6):1427-34.
6. Simpson D, Curran MP, Oldfield V, et al. Ropivacaine: a review of its use in regional anaesthesia and acute pain management. Drugs 2005;65(18):2675-717.

7. McClure JH. Ropivacaine. British Journal of Anaesthesia1996;76:300-7.

8. Thimmappa M, Madhusudhana R, Potli S, et al. A comparative study of epidural ropivacaine $0.75 \%$ alone with ropivacaine plus clonidine and ropivacaine plus dexmedetomidine for lower abdominal and lower limb surgeries. World Journal of Pharmacy and Pharmaceutical Sciences 2014;3(4):1218-30.

9. Lauretti GR, de Oliveira R, Perez MV, et al. Postoperative analgesia by intra-articular and epidural neostigmine following knee surgery. J Clin Anesth 2000;12(6):444-8.

10. Ummenhofer WC, Brown SM, Bernards CM. Acetylcholinesterase and butyrylcholinesterase are expressed in the spinal meninges of monkeys and pigs. Anesthesiology 1998;88(5):1259-65.

11. Artico M, Cavallotti C. Catecholaminergic and acetylcholine esterase containing nerves of cranial and spinal dura mater in humans and rodents. Microsc Res Tech 2001;53(3):212-20.

12. Craig HJ. Anaesthetic gases. In: Dundee JW, Clarke RS, McCaughey W. eds. Clinical anesthetic pharmacology. New York: Churchill Livingstone 1990;126:127-36.

13. Singh V, Imran M, Kaushal D. A randomized controlled study to compare the analgesic and hemodynamic effects of intrathecal ropivacaine with or without neostigmine and dexmedetomidine in lower limb surgeries. International Journal of Medical and Applied Sciences 2014;3(4):286-95.

14. Bajwa SJ, Bajwa SK, Kaur J, et al. Dexmedetomidine and clonidine in epidural anaesthesia: a comparative evaluation. Indian Journal of Anaesthesia 2011;55(2): 116-21.

15. Hood DD, Eisenach JC, Tuttle R. Phase I safety assessment of intrathecal neostigmine methylsulfate in humans. Anesthesiology 1995;82(2):331-43.

16. Kanazi GE, Aouad MT, Jabbour-Khoury SI, et al. Effect of low-dose dexmedetomidine or clonidine on the characteristics of bupivacaine spinal block. Acta Anaesthesiol Scand 2006;50(2):222-7.

17. Bajwa SJS, Bajwa SK, Kaur J, et al. Admixture of clonidine and fentanyl to ropivacaine in epidural anesthesia for lower abdominal surgery. Anesth Essays Res 2010;4(1):9-14.

18. Kaya FN, Yavascaoglu B, Turker G, et al. Intravenous dexmedetomidine, but not midazolam, prolongs bupivacaine spinal anesthesia. Can J Anaesth 2010; 57(1):39-45.

19. Sabbe MB, Penning JP, Ozaki GT, et al. Spinal and systemic action of the alpha 2 receptor agonist dexmedetomidine in dogs. Antinociception and carbon dioxide response. Anesthesiology 1994;80(5):1057-72.

20. Liu SS, Hodgson PS, Moore JM, et al. Dose-response effects of spinal neostigmine added to bupivacaine spinal anesthesia in volunteers. Anesthesiolog 1999;90(3): 710-7. 